\title{
Strengthening the Supervision on Liaison of The Judicial Commission in The East Kalimantan: A Study to Create a Clean and Responsible Judiciary
}

\author{
Dinny Wirawan Pratiwie ${ }^{1}$ and Wahyuni Safitri ${ }^{2}$ \\ \{dinipratiwie@gmail.com ${ }^{1}$, rindming@gmail.com ${ }^{2}$ \} \\ 1,2Universitas Widya Gama Mahakam, Samarinda, Kalimantan Timur, Indonesia
}

\begin{abstract}
The objectives of this study are (1) to analyze efforts to strengthen the supervisory function carried out by the Liaison of the Judicial Commission East Kalimantan region (2) to identify the inhibiting factors for the implementation of the supervisory function in the implementation of the justice system, especially in Samarinda City. This study uses a normative juridical research method supported by data from interviews with the Liaison Office of the East Kalimantan Regional Judicial Commission. The results obtained from this study (1) Liaison of the Judicial Commission of the East Kalimantan region has carried out strengthening the supervisory function through open supervision methods, closed supervision, preventive supervision through the selection of prospective Judges, supervision through the collection of opinions from the public and academics, and through the Early Detection program. (2) Constraints faced are related to the limited liaison authority of the Judicial Commission in the region, community participation, and limited human resources.
\end{abstract}

Keywords: Liaison of the Judicial Commission, Supervision, Judicial System.

\section{Introduction}

Independent, impartial, competent, transparent, accountable and dignified judiciary capable of upholding the authority of the law, legal protection, legal certainty and justice constitute a sine qua non condition or an absolute requirement in a state based on law. The judiciary is the main pillar in law and justice enforcement and the process of building national regulations [1]. Important factors that must be considered in order to realize a clean and authoritative judiciary, as quoted by Ridarson Galingging in the New Mexico Judicial Ethnics Handbook, among others:

1. Integrity and Independence

The principle of integrity and independence is very important and inherent in a judge[2]. This integrity refers to personality and character that is honest, cannot be bought and are moral. While it means independence could not be affected 
either by superiors, peers, and the agency either executive or legislative in making a decision on a case that is being handled.

2. Impropriety and Appearance of impropriety

Every behavior and actions of a judge should not be contrary to decency prevailing in a society. Behave in accordance with propriety that must be visible in the daily life of a judge. Indeed, a judge behaves standard was far higher than the standards of conduct that apply to a lawyer or the public in general. Many things can be done by most people but be improper or inappropriate if made by a judge.

3. Respects for the law

Respect for the law must be reflected in the daily life of a judge. Not only that, the respect of the law should also be reflected in the way the judge leading the trial, in treating an accused, treats witnesses and lawyers, as well as in the decision made.

4. Impartiality

This principle requires judges to be neutral, not to side with one of the litigants, plaintiffs and defendants in civil cases, defendants and legal counsel and prosecutors in criminal cases. This impartiality principle requires the judge to not allow family, social relationships, political or other relationships affect their behavior during the trial or in making a decision on a case that is being handled[3].

A judge in using their judicial power shall avoid power abuses, as far as possible avoid errors of law, avoid establishing a unilateral communication with litigation parties, comply with process of law, develop a good attitude in public speaking, writing and teaching, business and financial activities, social and political activities, in order to achieve a clean and authoritative judiciary [3].

According to Jimly Asshiddiqie as cited by Ni'matul Huda, the objective of the establishment of Judicial Commission in the structure of judicial supremacy is to involve members of society outside the official structure of Indonesian parliamentary institution in the process of promotion, performance evaluation, and possibly the termination of a judge. The goals of the efforts are to keep and enforce reputation, noble dignity, and judge good behaviors in order to enforce truth and justice according to the principle of belief in the one supreme God. With its honor and noble dignity, an independent and impartial judicial supremacy is expected to be achieved, while at once to be balanced with accountability principle of judicial supremacy, both in law and ethic perspectives. For those purposes, an independent surveillance institution is required for the judges themselves[4].

As cited by Diah Savitri, Sirajuddin dan Zulkarnain in their book entitled "Komisi Yudisial dan Eksaminasi Publik: Menuju Peradilan yang Bersih dan Berwibawa" ("Judicial Commission and Public Examination: To a Clean and Authorative Judiciary") stated that structurally the position of Judicial Commission is equal to the positions of Supreme Court and Constitutional Court. However, functionally, the nature of its role is auxiliary to judicial supremacy institution [5]. Despite the fact that its power 
is related to judicial supremacy, the Judicial Commission does not perform judicial supremacy functions, since it is not expected to become a code-of-law enforcement institution; instead it is a code-of-ethic enforcement institution [5].

Behaviors of a judge are dependents to a number of aspects including: (1) Intellectual Honesty (2) Compliance to the valid laws (3) Transparency in wealth and assets possession (4) Conduct of prudential principles in every task (5) Avoidance of every action that may risk trustworthiness of judicial institution [6]. A judge, a person who is expected to be the last line of defense in achieving fulfillment of justice needs of the society through their judgments, does in fact contribute to defects in law enforcement. The important roles of law enforcers, a judge in this case, remind us of the statement of Taverne, as cited by Eman Suparman in the book written by Satjipto Raharjo entitled 'Hukum Progressif, Sebuah Sintesa Hukum Indonesia' ('Progressive Law: A Law Synthesis in Indonesia'), 'Give me a good prosecutor and judge, so I will be able make a good judgment even with a bad rule' [7].

A surveillance conducted by Judicial Commission involves a range of efforts from preventive surveillance to repressive surveillance, in order to keep and enforce reputation, noble dignity and behavior of judges [8]. Surveillance function of Judicial Commission, as required in the Indonesian 1945 Constitution (UUD 1945), mainly focuses on the judge's surveillance as individual, not directly on Supreme Court as an institution. This means that a Judicial Commission is not purposed to conduct surveillance to judicial administration e.g. staffing, financial and case administrations[9]. Judicial Commission in Indonesia is related to South European Judicial Commission, which is independent and conducts disciplinary actions against judges, in order to maintain judicial independence [10].

Judicial Commission, in maintaining and enforcing judge reputation, will consider whether or not the decided judgment complies with judge reputation and justice sense in the middle of society[11]. On the other hand, in order to maintain and enforce noble dignity of a judge, Judicial Commission must conduct surveillance regarding whether or not a judge profession has fulfilled the professional etiquettes and gained society trust, and observe and ensure that judges keep their human natures, conscience and reputation, by avoiding undignified actions [8].

Considering the growing importance of roles and purposes of Judicial Commission, it is seemingly unequal to vast reach of judicial observation and number of judges available in Indonesia, and lack of infrastructure possessed by Judicial Commission[12]. For that reason, it is compulsory that Judicial Commission role be strengthened along with the function of Liaison of Judicial Commission in regions, and expansion of cooperation access, with financial supports for network operational expenses, formed by Judicial Commission [13]. Promotion of Liaison of Regional Judicial Commission is an effort in strengthening roles and purposes of Judicial Commission as regulated in Article 3, Section (2) of Constitution Number 18 Year 2011 regarding Judicial Commission.

To strengthen roles of Judicial Commission, simply give more power to Liaison of Judicial Commission in their duties and purposes[14]. The strengthening of competence, quality and integrity of Liaison Officers of Judicial Commission is a part of providing with Working Contract Based Government Employees. Also, a sequence of 
local government support regarding fulfillment of infrastructure needs of Regional Liaison of Judicial Commission [15].

Considering the above facts, it is required to conduct a study of related topics regarding the efforts in strengthening the surveillance purposes of Liaison of Judicial Commission of East Borneo Province in order to obtain a clean and authoritative judiciary, along with impeding factors faced by Liaison of Judicial Commission of East Borneo Province, especially in the city of Samarinda.

\section{Methodology}

The method used in this research is by collecting secondary data through literature study involving constitutional rules which consists of (1) Constitutional Number 48, Year 2009 Regarding the Judicial Supremacy; (2) Constitutional Number 18, Year 2011 Regarding Judicial Commission; (3) Rules of Judicial Commission Number 1, Year 2012 Regarding Forming, Structure, and Working Procedure of Liaison of Regional Judicial Commission; (4) Rules of Judicial Commission Number 1, Year 2017 Regarding Forming, Structure, and Working Procedure of Liaison of Regional Judicial Commission.

The next step was by conducting a field study at the office of Liaison of Judicial Commission of East Borneo. In this step, the researcher collected data by directly interviewing the Assistant of Liaison of Judicial Commission of East Borneo. Interview was conducted directly and systematically by using an interview guide.

The results of data collection and through literature study and field study were then analyzed using quantitative approach, and finally described according to the discussion in question.

\section{$3 \quad$ Result and Analysis}

\subsection{Strengthening of Surveillance Purposes of Liaison of Judicial Commission of East Borneo}

According to duties and authority as mandated by Rules of Judicial Commission Number 1, Year 2017 Regarding Forming, Structure, and Working Procedure of Liaison of Regional Judicial Commission to the Liaison of Judicial Commission (hereinafter referred to as LJC), therefore, surveillances that have been conducted by LJC including:

1. Direct and Open Trial Observation.

The surveillance model conducted by LJC, especially in the city of Samarin$\mathrm{da}$, is done by conducting an open and direct trial observation. In this observation, LJC sends notifications by attaching letters of assignment to conduct observation during a trial. In this case, the observing LJC officer is entitled to record the process during trial. This kind of observation is not very effective due to the judge tendencies to intentionally keep their attitudes so as not to give the impression of breaking codes of ethic and conduct of judges dur- 
ing observation. Therefore, it can almost be certain that the result of the observation will always show the good trial process and judge behavior as required by the rules. In this observation, LJC officer conducts the observation in trial room thoroughly. If a number of nonconformities are found, they will be taken as findings by the officer of LJC during the trial process.

2. Closed, initiatively Trial observation.

This observation is conducted according to initiative action of LJC and public complaints. The complainer, in this case, is the improperly-treated member of society by behavior of judicial panel in their trial case. In this observation, the officer of LJC attends the trial without prior notice and without showing the letter of assignment, however, the officer of LJC is not entitled to record the trial process, only to observe and take notes whether or not the results were accordance to the public complaints. This observation is effective enough, due to a fact that the officer of LJC can directly find nonconformities, if any, and that it is almost certain that judicial panel being complained will act naturally, as they do not notice the presence of officer of LJC observing the trial process.

3. Surveillance in a Form of Academic Opinion Collection.

This observation is done by involving academics and Non-governmental Organizations. In this method, collection of opinion or opinion polling is conducted to observe judicial improvement, and trials in judicial institution.

Some of views and opinions and event experience of events will be the parts of LJC findings in the judicial system in Samarinda. With this collection of opinions, it is expected to be able to help LJC in improving surveillance performance on judicial system and judge behavior being questioned

4. Early Protection Program

This program is just initiated by LJC of East Borneo, by digging for information regarding the judges who allegedly broke the codes of ethics and conduct of judges, and their performances, discipline or professionalism. The information is gained from staff in judicial institution, which is a lawyer who has the experience in working with the judge in question. This program is expected to bring about an independent evaluation on judge performance, and is an effort in preventing the breaking of codes of ethics and conduct of judges, especially in East Borneo.

5. Preventive Surveillance by Determining Criteria for Judge Candidates and Judge Promotion.

The objective of this preventive surveillance is to conduct a strict screening in the promotion process a judge, so as to prevent or minimize the potential breaking of codes of ethics and conduct of judges in the future.

The surveillance efforts by LJC in the region have been well-conducted, however, an expansion of authority of regional LJC needs to be given, especially the authority in taking immediate measures to public reports given to LJC, because it can be said that Regional LJC is the spearhead of surveillance performance on regional judge behaviors. Moreover, Regional LJC has a better understanding regarding the society and cultural characteristics in the area which vary from one place to another. Thus, 
society trust and faith in LJC can be improved. In other words, once a report from society against behavior of judicial panel or a particular judge is received, LJC has the capability to take an immediate measure for the situation, in order to give a feeling of certainty and trust to the complaining member of society, that the report is immediately processed without delay or even without waiting until the judgment is decided in the case being faced. This is done as not to leave the impression of futility in public complaining to LJC.

\subsection{The Impeding Factors}

Some of obstacles faced by LJC of East Borneo in conducting surveillance purposes on judge behaviors, i.e.:

1. Limited Authority of LJC

Limited Authority of LJC in conducting the follow-up process on disadvantaged-public complaints in a case being faced, either in material and nonmaterial disadvantage they claim. In the stage of complaining, it is expected that the member of society giving the complaints be given a certainty impression in their reports to LJC, and the certainty they expect to have is not the certainty given after the judge decision is made, instead, a prior-todecision certainty. It means that once the report is delivered by society to LJC, at least the judicial panel that allegedly breaks the codes of ethics and conduct of judges is immediately processed by LJC, or even replaced for the case being questioned in order to give protection to society in trial process against improper behavior of judicial panel.

2. Public Active Role

The active role of public has been obstacle not only due to lack of public recognition in the existence and the purposes of $\mathrm{LJC}$, but also due to public reluctance in doing reports, because public assumes that the measure will spend much time and finally causes time delay in finishing the case in trial, or even the report is still being verified by LJC, while the trial has already reached final decision. Those are factors that make society reluctant in giving some reports, and seemingly give in to violations by judicial panel.

3. Human Resources

Lack of Human Resources causes ineffective working and purpose performances. It is possible that if one of LJC staffs falls ill, or whenever something happens which prevent them from doing their activities, the LJC performance will also suffer.

Some of those obstacles are worth of concern from Judicial Commission of the Republic of Indonesia, in order to maximize the performance of LJC and to maximize surveillance on judges and trial process to make them effective. 


\section{Conclusion}

The strengthening efforts of surveillance purposes of LJC have been well-conducted. It is indicated by some surveillance models conducted by LJC including some initiative efforts, public reports, opinion collection with academics and Non-governmental Organizations (NGO), which involves an Early Detection Program which is initiated as the realization of JLC integration. However, with all obstacles faced by JLC of East Borneo, mainly regarding the lack of public role involvement due to the lack of trust in LJC performance itself, it is needed that an expansion of JLC authority is given, especially in East Borneo in involvement in public report handling, from the stage of verification to the stage of investigation, in order to immediately finish the follow-up measurements on a report, so as to increase public trust in the performance of Regional JLC.

Education and training of Human Resources are important in JLC to improve the competence of regional officers. In order to solve the Human Resource or JLC officer problem, a digital reporting or complaining program can be used, with an automatic feature and easier access. The currently available online service provided by the Republic of Indonesia Judicial Commission is adopted by JLC, but with improvements including easier access and feature or program that is easier for regional public to understand. On the other hand, to cope with the limited Human Resources in observing the trial process, JLC can make cooperation with universities in providing their students with a media of learning, regarding the trial process, surveillance of judges, so as to make the students the whistle blowers, in case some findings are discovered during the trial.

\section{References}

[1] B. Sutiyoso, "Penguatan Peran Komisi Yudisial dalam Penegakan Hukum di Indonesia," Hukum, vol. 18, no. 2, pp. 266-284, 2011.

[2] C. Forsyth, "The failure of institutions: The South African judicial service commision and the Hlophe Saga," in The Culture of Judicial Independence: Conceptual Foundations and Practical Challenges, University of Cambridge, United Kingdom: Brill, 2011, pp. 69-84.

[3] R. Galingging, "Peran komisi yudisial dalam membangun peradilan yang bersih dan berwibawa," ADIL J. Law, vol. 7, no. 1, pp. 1-17, 2017.

[4] N. Huda, Hukum Tata Negara Indonesia, Revisi. Jakarta: Rajawali Press, 2014.

[5] D. Savitri, "Kewenangan Komisi Yudisial Dan Dewan Perwakilan Rakyat Dalam Pengangkatan Hakim Agung," J. Cita Huk., vol. I, no. 2, pp. 263-284, 2013.

[6] A. Nurudin, "Diskresi Yudisial: Antara Keadilan Dan Pencitraan," Masal. Huk., vol. 45, no. 1, pp. 18-24, 2016.

[7] E. Suparman, "Menolak Mafia Peradilan: Menjaga Integritas Hakim-Menyelaraskan Perbuatan dan Nuraninya," J. Huk. Pembang., vol. 47, no. 1, pp. 61-82, 2017.

[8] M. Muhtarom, "Perkembangan Lembaga Peradilan Indonesia Di Era Reformasi," Ishraqi, vol. IV, no. 2, pp. 145-159, 2008.

[9] G. Majone, "The regulatory state and its legitimacy problems," West Eur. Polit., vol. 22, no. 1, pp. 1-24, 1999. 
[10] T. Syahuri, "Peran Komisi Yudisial Dalam Pengawasan Hakim Terhadap Dilema Independensi Kekuasaan Kehakiman."

[11] E. J. Powell and J. K. Staton, "Domestic judicial institutions and human rights treaty violation," Int. Stud. Q., vol. 53, no. 1, pp. 149-174, 2009.

[12] J. Ferejohn, "Independent judges, dependent judiciary: Explaining judicial independence," South. Calif. Law Rev., vol. 72, no. 2-3, p. 353, 1999.

[13] B. Bertin, "Fungsi Pengawasan Komisi Yudisial terhadap Perilaku Hakim Dihubungkan dengan Independensi Hakim sebagai Pelaku Kekuasaan Kehakiman," J. Ilmu Huk. Leg. Opin., vol. 1, no. 3, pp. 1-10, 2013.

[14] R. La Porta, F. López-de-Silanes, C. Pop-Eleches, and A. Shleifer, "Judicial checks and balances," J. Polit. Econ., vol. 112, no. 2, pp. 445-470, 2004.

[15] F. Wajdi, "Optimalisasi Peran Penghubung Komisi Yudisial," in Optimalisasi Wewenang Komisi Yudisial dalam Mewujudkan Hakim Berintegritas, I., Jakarta: Sekretariat Jenderal Komisi Yudisial Republik Indonesia, 2016, pp. 119-144. 